scientific associations received subsidies amounting to 606,000 francs. The thirty-eighth annual report of the Foundation (Fondation Universitaire. Trentehuitième Rapport Annuel, 1957-1958. Pp. 148. Bruxelles: Fondation Universitaire, 1959) which gives these figures, includes a list of beneficiaries during the year, as well as some notes on institutions with which the Foundation has connexions. It also includes a list of bursars for 1958-59 under the Belgian American Education Foundation, Inc., both in Belgium and in America. Of the 29,651 university students enrolled in $1957-58,81.5$ per cent were men and 18.5 per cent women : 11.35 per cent were in science, 25.33 per cent in medicine and pharmacy, 11.62 per cent in applied science, 2.52 per cent in agronomy, $6 \cdot 15$ per cent in social, political and economic science, and $\mathbf{1 3} \cdot 16$ per cent in commercial science. Of 4,770 diplomas obtained in 1956-57,630 were in science, 1,035 in medicine and pharmacy, 33 in veterinary medicine, 405 in applied science, 151 in agronomy, 266 in social, political and economic science, and 654 in commercial science.

\section{Industrial Psychology Grant Increased}

THE Department of Scientific and Industrial Research is to continue its annual grant to the National Institute of Industrial Psychology for a further five years. The amount is to be raised from $£ 4,000$ to $£ 6,000$ a year, on the understanding that the Institute will increase to $£ 9,000$ a year its own income from membership subscriptions and special contributions for long-term research. The Department of Scientific and Industrial Research is also to add another $£ 100$ a year for every $£ 100$ of grantearning income which the Institute can obtain in excess of the qualifying $£ 9,000$, up to a maximum of another $£ 6,000$ a year. This means that if the Institute can raise $\mathfrak{1 1 5 , 0 0 0}$ a year from industry, the Government will give it $£ 12,000$. The grant and the grant-earning income have to be put in a special fund and used only for long-term research. Among research projects now in train are : an inquiry into workers' attitudes to the opportunities and rewards offered by their jobs, which may have a bearing on personnel policies ; an investigation into the relation between satisfaction and efficieney on the job ; a study of industrial management structure and efficiency ; and experiments on tests for manual skill. The Institute has received many inquiries from industry recently about the special tests it has devised for selecting suitable school-leavers to be engineering apprentices.

\section{Australian Atomic Energy Commission Research Grants}

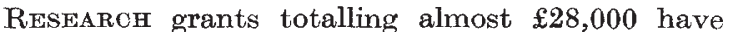
recently been awarded by the Australian Atomic Energy Commission in support of research under contract in seven Australian universities. Fields covered include chemistry, physics, geology, mining, electrical, metallurgical and chemical engineering, and the biological sciences. The grants have been made for work in fields which will contribute to the Commission's own work in developing civilian uses of atomic energy.

\section{Alkali and Similar Works in Britain}

ThE ninety-fifth report of the Chief Inspector on Alkali, ete., Works in England and Wales covering the year 1958 notes an increase in the number of works registered under the Act from 872 at the end of 1957 to 2,160 at the end of 1958. It also shows an increase in the number of separate processes from 1,733 to 3,412 in consequence of the extensions of the list of scheduled works and of noxious or offensive gases under the Alkali, etc., Works Order, 1958. Many of the new registrations relate to very large undertakings, particularly as regards the iron and steel industry and the newer electric power stations. The result of these increases is that the staff of the inspectorate has been increased, and it will now be necessary to adjust the internal organization. The 7,142 visits and inspections during the year included 255 special visits by the chief and deputy chief inspectors and 32 by Mr. W. A. Damon, the former chief inspector, who continues to serve in a special advisory capacity. Several visits were again paid to establishments of the Atomic Energy Authority, and discussions with the Authority during 1958 covered problems arising out of the nuclear power problem, particularly as regards the increased scale of processing uranium for use as a fuel and of irradiated uranium from the projected nuclear power installations. Considerable interest has been shown by local authorities in clean air matters and in the processes scheduled by the 1958 Order, and friendly and adequate liaison and co-operation appear to have been established. There were twelve infractions of pre-1958 processes compared with seventeen in 1958, and of these, six related to escapes of acid gases in excess of statutory limits and six to failure to use 'best practicable means'. The Chief Inspector for Scotland reports 213 visits during the year, including 27 in connexion with the Alkali, et.c., Works (Scotland) Order, 1958, mainly about points of doubt in applications to register. In the course of $\mathbf{8 9}$ chemical tests, throe infringements were found, two in chamber sulphuric acid plants, which appeared to be quite inadvertent, and one at a plant for concentrating sulphuric acid. Two further infringements were noted during visual inspection of premises registered for distillation of tar.

\section{New Journal of Psychopharmacology}

LrTERATURe on psychopharmacology has hitherto either appeared as contributions to symposia, of which the past years have seen ever-increasing numbers, or been scattered in the periodicals of many disciplines, such as psychology, psychiatry, physio. logy, biochemistry and pharmacology. Psychopharmacologia is a new journal aiming at finding a single home for the investigations on the effect of drugs on behaviour carried out by workers with the greatest variety of training (Vol. 1, Fase. 1. Pp. $78+10$. 9.60 D.M. Maximal-preis 1959, 40 D.M. Maximal-preis 1960, 80 D.M. Berlin : SpringerVerlag, 1959). There will be some overlap with the recently launched periodical Biochemical Pharmacology as there will be with the Journal of Neurochemistry, but interest in this field has been so great in recent years that the editors will experience little difficulty in obtaining manuscripts of the highest standard. Papers will be accepted in English, French or German. The advisory board is recruited from Western Europe and North America. The first number contains a review and a number of original articles and makes interesting reading. It is to be hoped that psychopharmacologists, while keeping up with their own diseipline, will find time to read yet another integrating journal. 